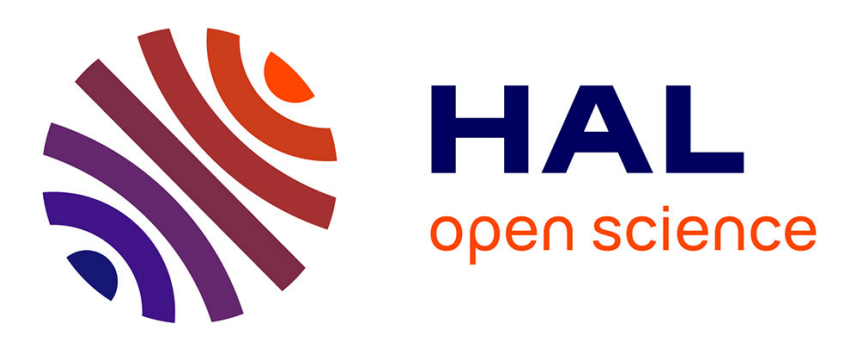

\title{
Bridging Amines with CO2: Organocatalyzed Reduction of CO2 to Aminals
}

Xavier Frogneux, Enguerrand Blondiaux, Pierre Thuéry, Thibault Cantat

\section{To cite this version:}

Xavier Frogneux, Enguerrand Blondiaux, Pierre Thuéry, Thibault Cantat. Bridging Amines with CO2: Organocatalyzed Reduction of CO2 to Aminals. ACS Catalysis, 2015, 5, pp.3983-3987. 10.1021/acscatal.5b00734. hal-01228582

\section{HAL Id: hal-01228582 \\ https://hal.science/hal-01228582}

Submitted on 30 Jan 2019

HAL is a multi-disciplinary open access archive for the deposit and dissemination of scientific research documents, whether they are published or not. The documents may come from teaching and research institutions in France or abroad, or from public or private research centers.
L'archive ouverte pluridisciplinaire HAL, est destinée au dépôt et à la diffusion de documents scientifiques de niveau recherche, publiés ou non, émanant des établissements d'enseignement et de recherche français ou étrangers, des laboratoires publics ou privés. 


\title{
Bridging Amines with $\mathrm{CO}_{2}$ : Organocatalyzed Reduction of $\mathrm{CO}_{2}$ to Aminals
}

\author{
Xavier Frogneux, ${ }^{\star}$ Enguerrand Blondiaux, ${ }^{\star}$ Pierre Thuéry and Thibault Cantat* \\ CEA, IRAMIS, NIMBE, CNRS UMR 368591191 Gif-Sur-Yvette Cedex, France \\ Fax: (+33) 1.6908.6640 E-mail: thibault.cantat@ cea.fr Homepage:http://iramis.cea.fr/Pisp/thibault.cantat/index.html \\ Supporting Information Placeholder
}

\begin{abstract}
The 4-electron reduction of $\mathrm{CO}_{2}$ in the presence of secondary aromatic amines is described for the first time to access aminals. Under metal-free hydrosilylation conditions, the four $\mathrm{C}-\mathrm{O}$ bonds of $\mathrm{CO}_{2}$ are cleaved and the organocatalysts are able to balance the reactivity of $\mathrm{CO}_{2}$ to promote the selective formation of two $\mathrm{C}-\mathrm{N}$ and two $\mathrm{C}-\mathrm{H}$ bonds. The methodology enables the formation of various symmetrical and unsymmetrical aminals.
\end{abstract}

KEYWORDS: $\mathrm{CO}_{2}$ - organocatalysis - amines - hydrosilylation - reduction - aminal

Because $\mathrm{CO}_{2}$ is a renewable, cost-efficient and non-toxic resource, it is a desirable carbon feedstock for the production of value-added chemicals and a lot of groups have focused their attention on designing new transformations involving $\mathrm{CO}_{2}$ over the last few years. ${ }^{1}$ In particular, the reductive functionalization of $\mathrm{CO}_{2}$ with nitrogen reagents has known tremendous developments using various types of reductants such as hydrosilanes, hydroboranes and dihydrogen. ${ }^{2}$ These reactions have enabled the conversion of $\mathrm{CO}_{2}$ into formamides, ${ }^{2 \mathrm{~b}, 3}$ formamidines ${ }^{4}$ and methylamines. ${ }^{5}$ Notably, the carbon oxidation state in these products is either +2 or -2 and the formation of $\mathrm{C}^{0}$ organic functional groups from $\mathrm{CO}_{2}$ remains a challenge. This trend reflects the higher electrophilicity of $\mathrm{C}^{0}$ groups compared to $\mathrm{C}^{+\mathrm{II}}$ functions in carbonyl derivatives. It is indeed well established that upon hydrogenation of $\mathrm{CO}_{2}$, formate derivatives can be accumulated while formaldehyde is an elusive species because its reduction to methanol is more rapid than the hydrogenation of formic acid. ${ }^{1 a}$ As a consequence of this limitation, only a few reports have tackled the formation of $\mathrm{C}^{0}$ species from $\mathrm{CO}_{2}$. Under hydrosilylation conditions, the selective reduction of $\mathrm{CO}_{2}$ into a bis(silyl)acetal species with triethylsilane has been revealed. ${ }^{6}$ Using a hydroborane reductant, Bontemps, Sabo-Etienne et al. successfully trapped transient formaldehyde, obtained from $\mathrm{CO}_{2}$, with 2,6diisopropylaniline, yielding the corresponding imine. ${ }^{7}$ To unlock new 4-electron reduction transformations of $\mathrm{CO}_{2}$, one should focus on the use of well-balanced catalysts, able to finely control the kinetics of $\mathrm{CO}_{2}$ reduction. In nature, acetogenic bacteria are able to produce over $10^{9}$ tons of acetic acid annually, following the Wood-Ljungdahl pathway (Scheme 1). ${ }^{8}$ In this biochemical cycle, $\mathrm{CO}_{2}$ is anchored to a diamine moiety and undergoes successive 2-electron reduction steps to yield a methylamine $\left(\mathrm{C}^{-\mathrm{II}}\right)$ after formation of the corresponding formamide $\left(\mathrm{C}^{+\mathrm{II}}\right)$, formamidine $\left(\mathrm{C}^{+\mathrm{II}}\right)$ and aminal
$\left(\mathrm{C}^{0}\right)$ intermediates. While $\mathrm{CO}_{2}$ conversion to formamides, formaminides and methylamines has been described, the synthesis of aminals ${ }^{9}$ directly from $\mathrm{CO}_{2}$ remains unknown and was only suggested as a possible intermediate in the $\mathrm{Ru}$-based methylation of amines. ${ }^{5 \mathrm{~b}}$ To open up the variety of products accessible from $\mathrm{CO}_{2}$, we describe herein the first catalytic synthesis of aminals by intermolecular coupling of two amines using $\mathrm{CO}_{2}$ as a $\mathrm{C} 1$-bridge.

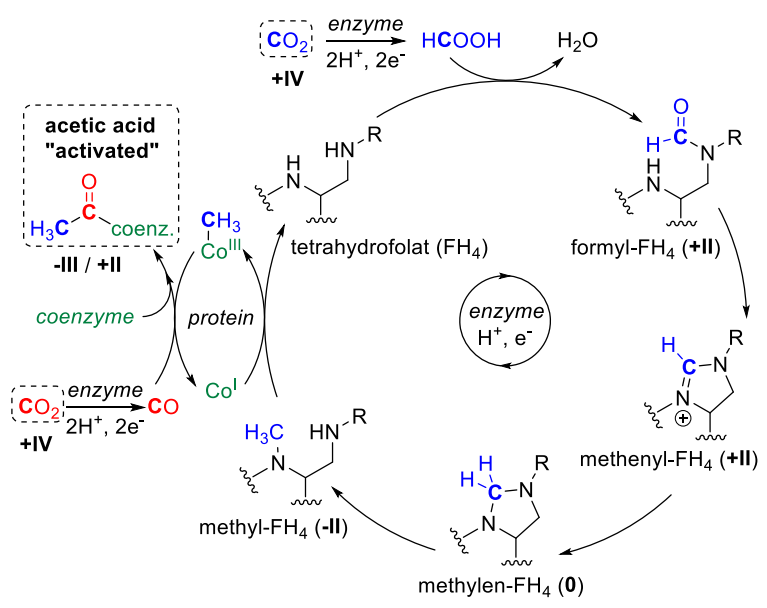

Scheme 1. Simplified mechanism of the Wood-Ljungdahl pathway for acetogenesis with $\mathrm{CO}_{2}$

Hydrosilanes are mild reductants, cheap, non-toxic with a redox potential well poised for $\mathrm{CO}_{2}$ reduction. Additionally, their slightly polar $\mathrm{Si}-\mathrm{H}$ bond can be activated with metal-free catalysts, using either Lewis bases or Lewis acids. ${ }^{10}$ Using phenylsilane as reductant, the reactivity between $N$ methylaniline (1a) and $\mathrm{CO}_{2}$ has been explored using a variety 
of organocatalysts able to form adducts with $\mathrm{CO}_{2}{ }^{11}$ or promote its reduction, such as guanidines, amidines, $N$-heterocyclic

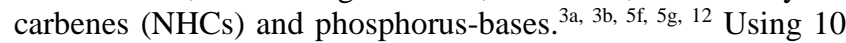
mol\% of the NHC It $\mathbf{B u}, \mathrm{CO}_{2}$ undergoes hydrosilylation in the presence of $N$-methylaniline (1a) in $\mathrm{CH}_{3} \mathrm{CN}$, and after $2.5 \mathrm{~h}$ at $80{ }^{\circ} \mathrm{C}, 76 \%$ of $\mathbf{1 a}$ was converted to the expected aminal $\mathbf{2 a}$ in $47 \%$ yield (Scheme 2). Nonetheless, methylamine $\mathbf{3 a}$ is also produced at a similar rate reaching $25 \%$ yield. Interestingly, after prolonged reaction time $(24 \mathrm{~h})$ methylamine $\mathbf{3 a}$ is formed as the main nitrogen product $(>95 \%)$, indicating that the aminal is an intermediate in the formation of $\mathbf{3 a}$ and that the catalyst is unable to prevent over-reduction of the $\mathrm{C}^{0}$ carbon center in 2a. Reducing the quantity of $\mathrm{CO}_{2}$ in the reaction vessel to circa 1 equiv. per amine somewhat improves the $\mathbf{2 a / 3} \mathbf{3}$ ratio of the reaction from 1.9 to 2.9 (Scheme 2).

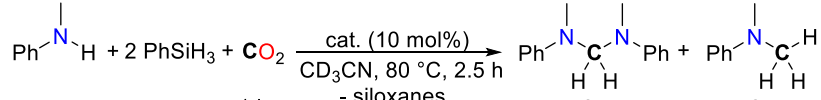

$$
\begin{aligned}
& \text { 1a } 1 \text { bar - siloxanes } \quad 2 a \quad 3 a \\
& \begin{array}{llll}
\sim 2 \text { eq. } & \text { ItBu } & 47 \% & 25 \% \\
\sim 1 \text { eq. } & \text { ItBu } & 52 \% & 18 \%
\end{array}
\end{aligned}
$$

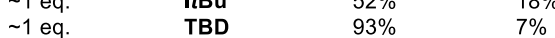

Scheme 2. Formation of aminal 2a via $\mathrm{CO}_{2}$ hydrosilylation

Table 1. Catalyst screening for the coupling of 1a to 2 a

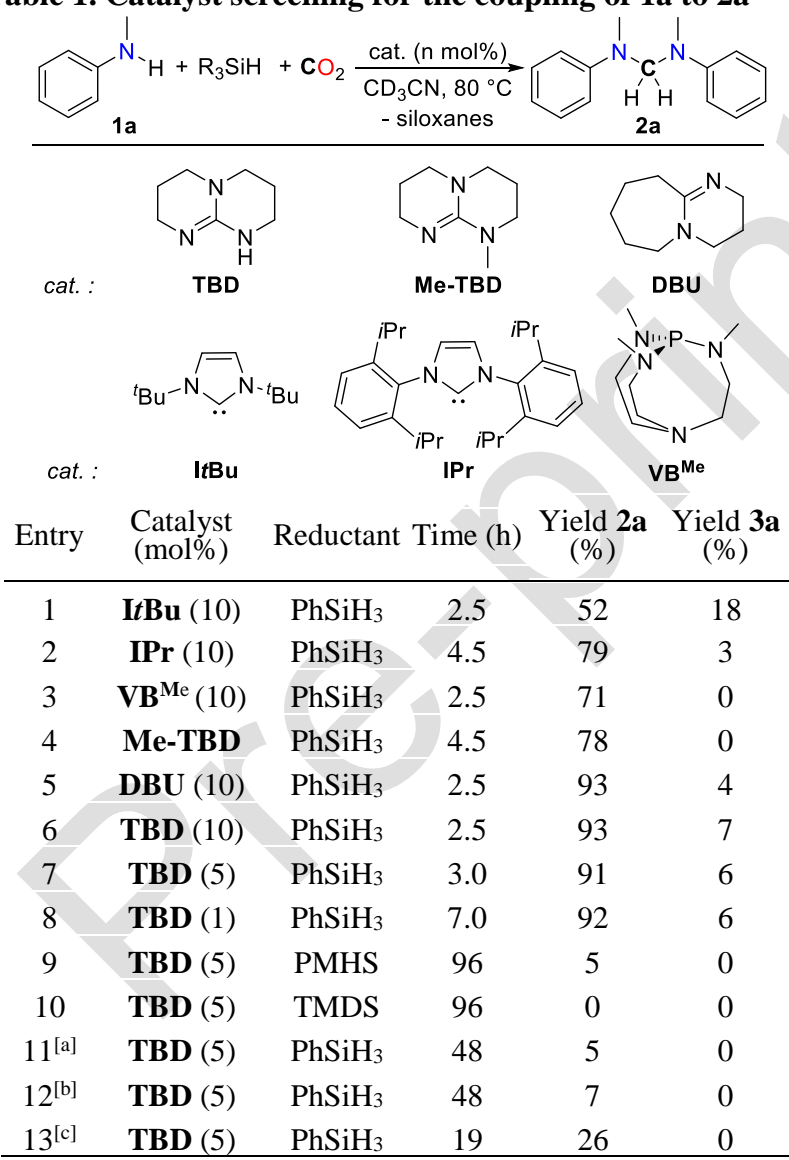

Reaction conditions: NMR tube $(2.5 \mathrm{~mL})$, catalyst, amine $(0.10 \mathrm{mmol})$, hydrosilane (6 eq. "Si-H"), solvent $(0.30 \mathrm{~mL}), \mathrm{CO}_{2}$ (1 bar). Yields determined by ${ }^{1} \mathrm{H}$ NMR with $\mathrm{Ph}_{2} \mathrm{CH}_{2}$ as internal standard. ${ }^{\left[{ }^{[a]}\right.}$ in toluene- $d_{8}{ }^{[\mathrm{b}]}$ in THF- $d_{8}{ }^{[\mathrm{cc}]}$ at RT.

Although encouraging, these results stress the need for a catalyst having a balanced reactivity in $\mathrm{CO}_{2}$ hydrosilylation, to avoid the methylation of the amine. While IPr, Verkade's base $\mathbf{V B}^{\mathrm{Me}}$ or guanidine Me-TBD enable the formation of $\mathbf{2 a}$ in up to $79 \%$ yield, the best activities and selectivities were obtained with 1,8-diazabicyclo[5.4.0]undec-7-ene (DBU) and 1,5,7-triazabicyclo[4.4.0]dec-5-ene (TBD) as catalysts for which the reaction was complete after $2.5 \mathrm{~h}$, yielding $93 \%$ of the desired aminal $\mathbf{2 a}$ and $\mathbf{3 a}$ as side-product (7\%) (Entries 26 , Table 1). As expected, no reaction occurred after $24 \mathrm{~h}$ in the absence of $\mathrm{CO}_{2}$ or catalyst. Importantly, with a low catalyst loading of $1 \mathrm{~mol} \%$ TBD, aminal $\mathbf{2 a}$ was still obtained in $92 \%$ yield after $7 \mathrm{~h}$ at $80^{\circ} \mathrm{C}$ (Entry 8, Table 1). Whereas polymethylhydrosiloxane (PMHS) or tetramethyldisiloxane (TMDS) are unreactive in the formation of $\mathbf{2 a}, \mathrm{Ph}_{2} \mathrm{SiH}_{2}$ exhibits a reactivity close to that of $\mathrm{PhSiH}_{3}$ (Entries 9-10, Table 1 and SI). The polarity of the solvent also has a positive influence on the transformation. Although 2a is formed in $<10 \%$ yield from $1 \mathrm{a}$ in toluene or THF $(\varepsilon<7.5)$, the corresponding yield increases to $91 \%$ in $\mathrm{MeCN}(\varepsilon=37.5)$ under analogous conditions (Entries 7, 11-12, Table 1). Finally, the conversion of 1a can proceed at RT, yet only $26 \%$ of the desired aminal could be obtained under these conditions and $49 \%$ of $\mathrm{N}$ methylformanilide was also formed (Entry 13, Table 1).

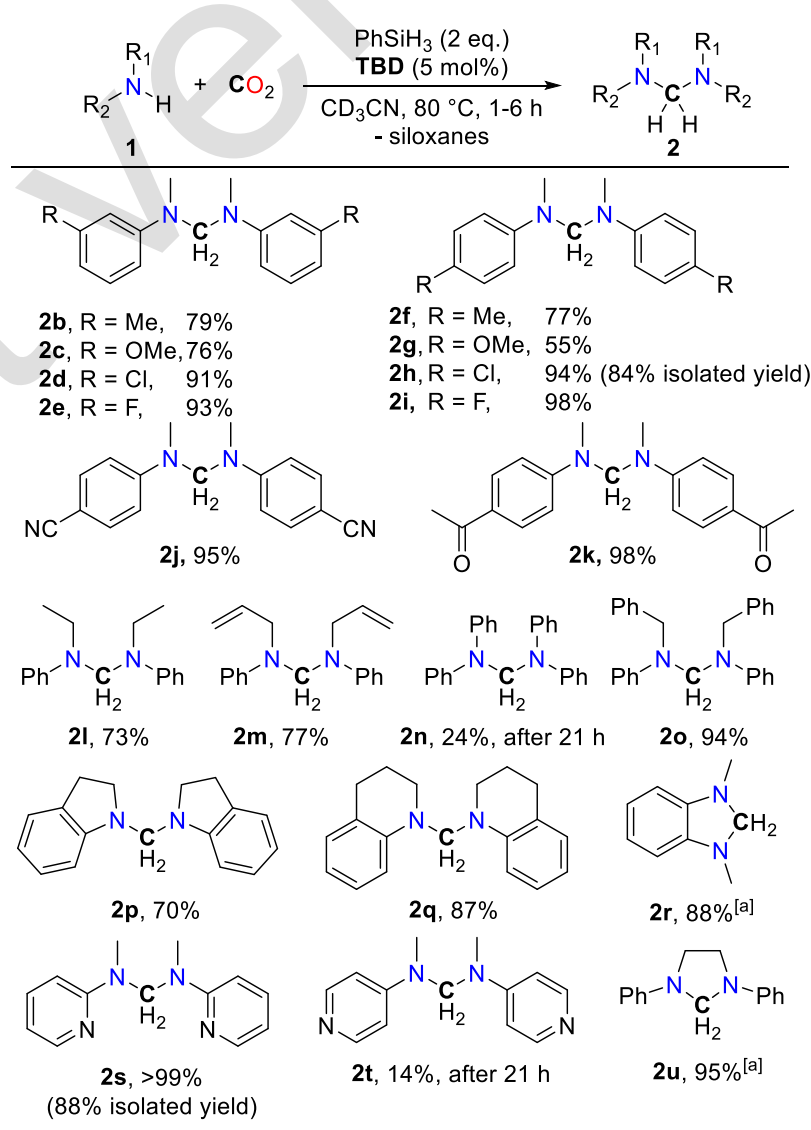

Reaction conditions: NMR tube $(2.5 \mathrm{~mL})$, TBD $(0.0050 \mathrm{mmol})$, amine $(0.10 \mathrm{mmol}), \mathrm{PhSiH}_{3}(0.20 \mathrm{mmol}), \mathrm{CD}_{3} \mathrm{CN}(0.30 \mathrm{~mL}), \mathrm{CO}_{2}(1 \mathrm{bar})$. Yields determined by ${ }^{1} \mathrm{H}$ NMR with $\mathrm{Ph}_{2} \mathrm{CH}_{2}$ as internal standard. ${ }^{\text {[a] }}$ amine $(0.050$ $\mathrm{mmol})$.

Scheme 3. Synthesis of aminals starting from secondary aromatic amines

Having in hand a selective and efficient catalytic system for this novel reaction, the coupling of various amines to aminals was attempted with $\mathrm{CO}_{2}$ (Schemes 3). Introducing electron- 
donating groups (EDGs) or electron-withdrawing groups (EWGs) on the aromatic ring of $N$-methylaniline, the corresponding aminals $\mathbf{2 b}$-2k were obtained in good yields (55$98 \%$ ), after $4 \mathrm{~h}$ at $80{ }^{\circ} \mathrm{C}$ in $\mathrm{CH}_{3} \mathrm{CN}$, in the presence of 2 equiv. $\mathrm{PhSiH}_{3}$ and $5 \mathrm{~mol} \%$ TBD; and negligible over-reduction was observed within $18 \mathrm{~h}$. Importantly, the reduction of $\mathrm{CO}_{2}$ to aminals is also chemoselective and oxidizing groups such as a nitrile or ketone are tolerated, as exemplified in the formation of $\mathbf{2 j}$ (95\% yield) and $\mathbf{2 k}$ (98\% yield). Indeed, crystals of $\mathbf{2 k}$ grown from the crude mixture confirmed the presence of the untouched carbonyl group and, hence, the ability of the catalyst to avoid over-reduction (Figure 1).

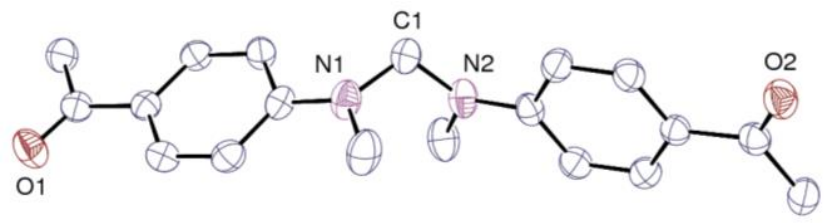

Figure 1. Molecular structure of $2 \mathrm{k}$ with displacement ellipsoids drawn at the $50 \%$ probability level

In order to widen the scope of aminal compounds available from the present methodology, the influence of the substituent on the nitrogen atom has been investigated. $N$-ethylaniline (11) and $N$-allylaniline (1m) were converted in good $73 \%$ and $77 \%$ yields to $\mathbf{2}$ and $\mathbf{2 m}$, respectively. The bulky $N$-benzylaniline gave the desired product 20 in $94 \%$ after $2 \mathrm{~h}$ at $80{ }^{\circ} \mathrm{C} . \mathrm{N}, \mathrm{N}$ diphenylaniline only furnished $24 \%$ of $2 \mathbf{n}$ after $21 \mathrm{~h}$, presumably because of its poor nucleophilicity. Cyclic amines such as indoline (1p) and 1,2,3,4-tetrahydroquinoline (1q) were converted to their aminal analogues $\mathbf{2 p}$ and $\mathbf{2 q}$ in good $70 \%$ and $87 \%$ yields. The reaction is also viable with secondary heteroaromatic amines: the formation of $2 s$ from 2methylaminopyridine was accomplished quantitatively and $2 \mathrm{~s}$ was isolated in $88 \%$ yield after removal of the siloxanes byproducts. In contrast, the reaction with 4-methylaminopyridine resulted in the formation of the corresponding formamide as a major product $(85 \%)$ and only $14 \%$ of the aminal $2 \mathrm{t}$ were observed. Naturally, the formation of the heterocycle is favored over an intermolecular reaction for diamino substrates, thus providing $\mathbf{2 r}$ and $\mathbf{2 u}$ with excellent 88 and $95 \%$ yield, respectively. However, starting from an aliphatic amine such as morpholine, only the corresponding formamide was yielded and no trace of the aminal product could be detected by ${ }^{1} \mathrm{H}$ NMR. This observation may be due to the stronger nucleophilicity of aliphatic amines which facilitates the production of a formamide that is unproductive in the formation of aminals.

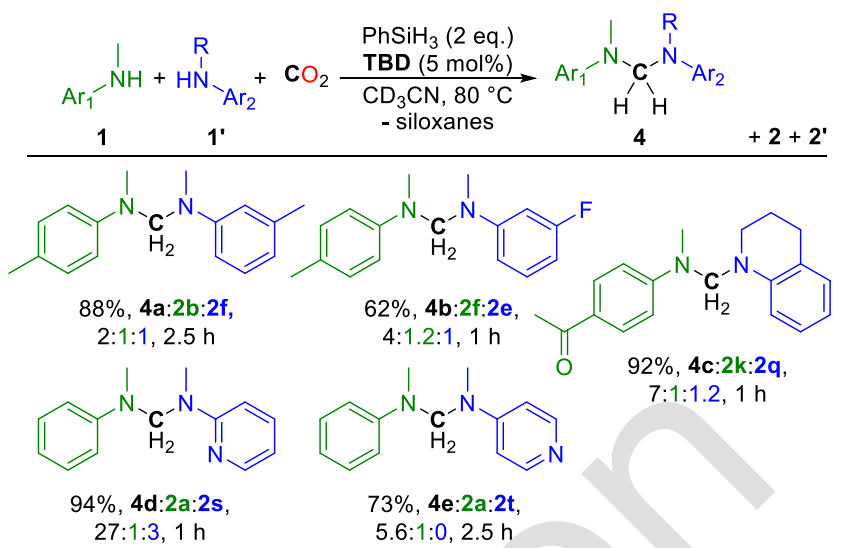

Reaction conditions: NMR tube $(2.5 \mathrm{~mL})$, TBD $(0.0050 \mathrm{mmol})$, amine 1 (0.050 mmol), amine 1' (0.050 mmol), $\mathrm{PhSiH}_{3}(0.20 \mathrm{mmol}), \mathrm{CD}_{3} \mathrm{CN}$ $(0.30 \mathrm{~mL}), \mathrm{CO}_{2}$ (1 bar). Average amines conversion determined by ${ }^{1} \mathrm{H}$ NMR with $\mathrm{Ph}_{2} \mathrm{CH}_{2}$ as internal standard (see SI).

\section{Scheme 4. Synthesis of unsymmetrical aminals}

The coupling of two different amines was identified as the next challenge facing this 4-component reaction, to access unsymmetrical aminals (Scheme 4). Reacting two amines with similar electronic properties (1b and 1f) with $\mathrm{CO}_{2}, \mathrm{PhSiH}_{3}$ and $5 \mathrm{~mol} \%$ TBD led to a statistical distribution of all possible aminals 4a, 2b and 2f (44/44/44\%). Nonetheless, when two amines of different nucleophilic character are used, the selectivity to the unsymmetrical aminals increases. For example, aminals $\mathbf{4 b}, \mathbf{4 c}, \mathbf{4 d}$ and $\mathbf{4 e}$ were obtained as the major products in $40,82,69$ and $61 \%$ yield, respectively, with the symmetrical aminals being formed as side products.

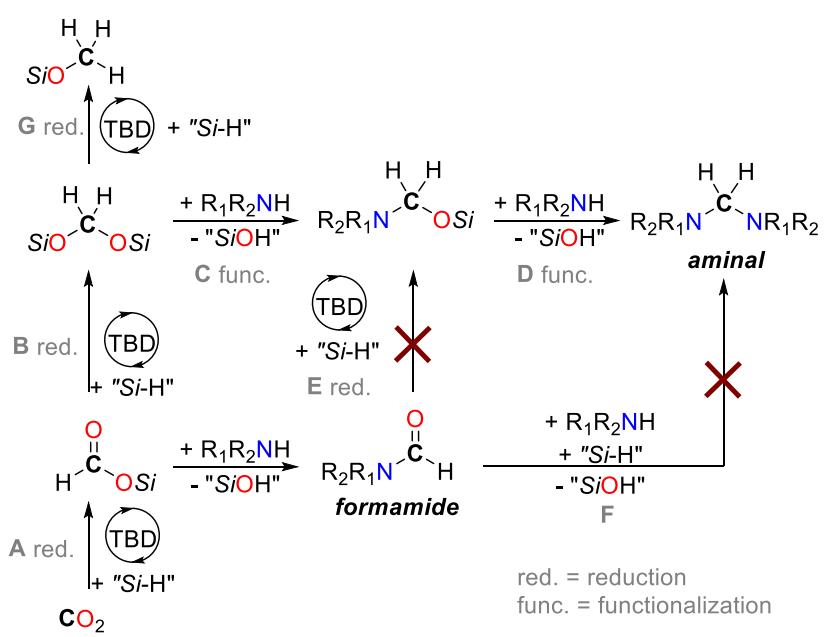

Scheme 5. Proposed pathway to access aminals The conversion of $\mathrm{CO}_{2}$ to aminals is a rare example of a catalytic reaction leading to the complete deoxygenation of $\mathrm{CO}_{2}{ }^{4}{ }^{4}{ }^{13}$ Overall, it involves the cleavage of four $\mathrm{C}-\mathrm{O}$ bonds and the formation of two $\mathrm{C}-\mathrm{H}$ bonds (reduction) and two $\mathrm{C}-\mathrm{N}$ bonds (functionalization). The nature of the organic intermediates involved in this reaction was investigated so as to explain the observed reactivities and facilitate future catalysts design. Possible pathways are depicted in Scheme 5. ${ }^{14}$ The reductive functionalization of $\mathrm{CO}_{2}$ to formamides is well established, TBD being a known catalyst for this transformation. ${ }^{3 a}$ Nonetheless, no 
reaction is observed when $\mathrm{N}$-methylformanilide 5a is reacted with $\mathrm{PhSiH}_{3}$ and $5 \mathrm{~mol} \%$ TBD, at $80{ }^{\circ} \mathrm{C}$, in the presence (step F) or absence ( step E, under $\mathrm{Ar}$ or $\mathrm{CO}_{2}$ ) of $\mathrm{N}$-methylaniline. Formamides thus appear as competition products in $\mathrm{CO}_{2}$ conversion to aminals. Classically, aminals can be prepared by condensation of amines onto paraformaldehyde and an alternative pathway for the formation of aminals from $\mathrm{CO}_{2}$ could thus rely on catalytic hydrosilylation of $\mathrm{CO}_{2}$ to a $\mathrm{C}^{0}$ bis(silyl)acetal species and subsequent nucleophilic addition of the two amine reagents. Using NHCs as catalysts, Zhang and Ying et al. have indeed detected successfully bis(silyl)acetal derivatives upon hydrosilylation of $\mathrm{CO}_{2}$, prior to the formation of silylmethoxides end-products. ${ }^{12 \mathrm{~b}}$ These considerations suggest that the conversion of $\mathrm{CO}_{2}$ to aminals proceeds via reduction of $\mathrm{CO}_{2}$ to a silylacetal species (steps $\mathbf{A}$ and $\mathbf{B}$ ) which undergoes two successive nucleophilic attacks (steps $\mathbf{C}$ and D). Although steps $\mathbf{C}$ and $\mathbf{D}$ are similar processes, they involve different electrophiles, namely a bis(silyl)acetal and an aminosilylacetal derivative. Because the bis(silyl)acetal is a stronger electrophile, the most nucleophilic amine should be rapidly consumed in step $\mathbf{C}$, so that unsymmetrical aminals can be selectively formed. According to this mechanism, the reduction and functionalization steps are consecutive but their relative rates are important to ensure $\mathrm{CO}_{2}$ conversion to the desired aminal while avoiding formamide and silylmethoxide competition products. Experimentally, highly nucleophilic amines (e.g. morpholine) indeed prevent the formation of aminals because they are readily converted to their corresponding formamides (vide supra) and catalysts able to promote the rapid conversion of $\mathrm{CO}_{2}$ to silylacetals will be necessary to access aminals from aliphatic amines. Conversely, electron poor amines such as diphenylamine are not nucleophilic enough to trap the bis(silyl)acetal intermediate and the latter is reduced to a silylmethoxide product prior to the formation of $\mathrm{C}-\mathrm{N}$ bonds (steps, A, B and G). Experimentally, silylmethoxide species $\left(\mathrm{CH}_{3} \mathrm{OSi}(\mathrm{O}) \mathrm{Ph}\right)$ were indeed observed as the major product in the conversion of diphenylamine with $\mathrm{CO}_{2}, \mathrm{PhSiH}_{3}$ and $5 \mathrm{~mol} \%$ TBD.

Capitalizing on this mechanism, we envisioned that other nucleophiles, such as malonates, could efficiently replace the amine reagents to promote the challenging formation of $\mathrm{C}-\mathrm{C}$ bonds from $\mathrm{CO}_{2}{ }^{15}$ In fact, addition of 2 equiv. $\mathrm{PhSiH}_{3}$ to diethylmalonate, under an atmosphere of $\mathrm{CO}_{2}$, resulted in the formation of $58 \% \mathrm{6}$ after $5 \mathrm{~h}$ at $80{ }^{\circ} \mathrm{C}$, in the presence of 5 mol\% TBD (Eq. 1). 6 formally results from the methylenation of two malonate moieties with $\mathrm{CO}_{2}$ and, to the best of our knowledge, it represents the first example of a homogeneous catalytic reaction leading to the formation of $2 \mathrm{C}-\mathrm{C}$ bonds at the $\mathrm{CO}_{2}$ carbon atom. This reaction is under further investigation in our laboratories.

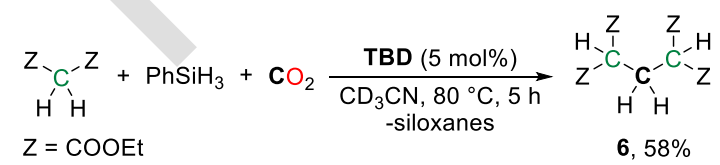

In conclusion, we have described herein a novel catalytic transformation to promote the conversion of $\mathrm{CO}_{2}$ to aminal derivatives via a 4-component reaction. The organocatalysts are able to balance the reactivity of $\mathrm{CO}_{2}$ reduction and selectively stabilize carbon( 0$)$ products for the formation of both symmetric and unsymmetric aminals.

\section{ASSOCIATED CONTENT}

\section{Supporting Information}

Details of experimental procedures, physical properties of new compounds, tables of crystal data, atomic positions and displacement parameters, anisotropic displacement parameters, and bond lengths and bond angles in CIF format. This information is available free of charge via the Internet at http://pubs.acs.org.

\section{AUTHOR INFORMATION}

\section{Corresponding Author \\ *thibault.cantat@cea.fr}

\section{Author Contributions}

\$These authors contributed equally.

\section{ACKNOWLEDGMENT}

For financial support of this work, we acknowledge CEA, CNRS, ADEME (Fellowship to E.B.), the CHARMMMAT Laboratory of Excellence, the University Paris-Saclay (Fellowship to X.F.) and the European Research Council (ERC Starting Grant Agreement n.336467). T.C. thanks the Foundation Louis D. - Institut de France for its support.

\section{REFERENCES}

1. (a) Goeppert, A.; Czaun, M.; Jones, J.-P.; Surya Prakash, G. K. Olah, G. A., Chem. Soc. Rev. 2014, 43, 7995-8048. (b) Fernandez-Alvarez, F. J.; Aitani, A. M. Oro, L. A., Catal. Sci. Technol. 2014, 4, 611-624. (c) Perathoner, S. Centi, G., ChemSusChem 2014, 7, 1274-1282. (d) Darensbourg, D. J., Chem. Rev. 2007, 107, 2388-2410. (e) Fiorani, G.; Guo, W. Kleij, A. W., Green Chem. 2015, 17, 1375-1389.

2. (a) Yang, Z.-Z.; He, L.-N.; Gao, J.; Liu, A.-H. Yu, B., Energy Environ. Sci. 2012, 5, 6602-6639. (b) Tlili, A.; Blondiaux, E.; Frogneux, X. Cantat, T., Green Chem. 2015, 17, 157-168.

3. (a) Das Neves Gomes, C.; Jacquet, O.; Villiers, C.; Thuery, P.; Ephritikhine, M. Cantat, T., Angew. Chem. Int. Ed. 2012, 51, 187-190. (b) Jacquet, O.; Das Neves Gomes, C.; Ephritikhine, M. Cantat, T., J. Am. Chem. Soc. 2012, 134, 2934-2937. (c) Motokura, K.; Takahashi, N.; Kashiwame, D.; Yamaguchi, S.; Miyaji, A. Baba, T., Catal. Sci. Technol. 2013, 3, 2392-2396. (d) Shintani, R. Nozaki, K., Organometallics 2013, 32, 2459-2462.

4. (a) Jacquet, O.; Das Neves Gomes, C.; Ephritikhine, M. Cantat, T., ChemCatChem 2013, 5, 117-120. (b) Yu, B.; Zhang, H.; Zhao, Y.; Chen, S.; Xu, J.; Huang, C. Liu, Z., Green Chem. 2013, 15, 95-99. (c) Hao, L.; Zhao, Y.; Yu, B.; Zhang, H.; Xu, H. Liu, Z., Green Chem. 2014, 16, 3039-3044.

5. (a) Jacquet, O.; Frogneux, X.; Das Neves Gomes, C. Cantat, T., Chem. Sci. 2013, 4, 2127-2131. (b) Li, Y.; Fang, X.; Junge, K. Beller, M., Angew. Chem. Int. Ed. 2013, 52, 95689571. (c) Beydoun, K.; vom Stein, T.; Klankermayer, J. Leitner, W., Angew. Chem. Int. Ed. 2013, 52, 9554-9557. (d) Li, Y.; Sorribes, I.; Yan, T.; Junge, K. Beller, M., Angew. Chem. Int. Ed. 2013, 52, 12156-12160. (e) Cui, X.; Zhang, Y.; Deng, Y. Shi, F., Chem. Commun. 2014, 50, 13521-13524. (f) Blondiaux, E.; Pouessel, J. Cantat, T., Angew. Chem. Int. Ed. 2014, 53, 12186-12190. (g) Das, S.; Bobbink, F. D.; Laurenczy, G. Dyson, P. J., Angew. Chem. Int. Ed. 2014, 53, 12876-12879. (h) Cui, X.; Dai, X.; Zhang, Y.; Deng, Y. Shi, F., Chem. Sci. 2014, 5, 649-655.

6. (a) Jiang, Y.; Blacque, O.; Fox, T. Berke, H., J. Am. Chem. Soc. 2013, 135, 7751-7760. (b) LeBlanc, F. A.; Piers, W. E. 
Parvez, M., Angew. Chem. Int. Ed. 2014, 53, 789-792. (c) Metsänen, T. T. Oestreich, M., Organometallics 2015, 34, 543-546.

7. Bontemps, S.; Vendier, L. Sabo-Etienne, S., J. Am. Chem. Soc. 2014, 136, 4419-4425.

8. Ragsdale, S. W. Pierce, E., Biochim. Biophys. Acta 2008, 1784, 1873-1898.

9. (a) Cheng, X.; Vellalath, S.; Goddard, R. List, B., J. Am. Chem. Soc. 2008, 130, 15786-15787. (b) Jurčík, V. Wilhelm, R., Tetrahedron 2004, 60, 3205-3210. (c) Huang, D.; Li, X.;

Xu, F.; Li, L. Lin, X., ACS Catal. 2013, 3, 2244-2247. (d) Neel, A. J.; Hehn, J. P.; Tripet, P. F. Toste, F. D., J. Am. Chem. Soc. 2013, 135, 14044-14047. (e) Guggenheim, K. G.; Toru, H. Kurth, M. J., Org. Lett. 2012, 14, 3732-3735. (f) Beifuss, U.; Ledderhose, S. Ondrus, V., Arkivoc 2005, 5, 147 173. (g) Shaibakova, M. G.; Titova, I. G.; Makhmudiyarov, G. A.; Ibragimov, A. G. Dzhemilev, U. M., Russ. J. Org. Chem. 2010, 46, 43-48.

10. (a) Oestreich, M.; Hermeke, J. Mohr, J., Chem. Soc. Rev. 2015, 44, 2202-2220. (b) Berkefeld, A.; Piers, W. E. Parvez, M., J. Am. Chem. Soc. 2010, 132, 10660-10661. (c) Wang, B. Cao, Z., RSC Adv. 2013, 3, 14007-14015. (d) Riduan, S. N.; Ying, J. Y. Zhang, Y., ChemCatChem 2013, 5, 1490-1496.

11. (a) Villiers, C.; Dognon, J. P.; Pollet, R.; Thuery, P. Ephritikhine, M., Angew. Chem. Int. Ed. 2010, 49, 3465-3468. (b) Duong, H. A.; Tekavec, T. N.; Arif, A. M. Louie, J., Chem. Commun. 2004, 112-113. (c) Voutchkova, A. M.; Feliz, M.; Clot, E.; Eisenstein, O. Crabtree, R. H., J. Am. Chem. Soc. 2007, 129, 12834-12846. (d) Pérez, E. R.; Santos, R. H. A.; Gambardella, M. T. P.; de Macedo, L. G. M.; Rodrigues-Filho, U. P.; Launay, J.-C. Franco, D. W., J. Org. Chem. 2004, 69, 8005-8011.

12. (a) Das Neves Gomes, C.; Blondiaux, E.; Thuéry, P. Cantat, T., Chem. Eur. J. 2014, 20, 7098-7106. (b) Riduan, S. N.; Zhang, Y. Ying, J. Y., Angew. Chem. Int. Ed. 2009, 48, 33223325 .

13. Khandelwal, M. Wehmschulte, R. J., Angew. Chem. Int. Ed. 2012, 51, 7323-7326.

14. A reaction pathway involving the formation of transient urea species was ruled out as TBD is unable to promote the hydrosilylation of quaternary ureas to aminals (see SI). This pathway is omitted in Scheme 6 for the sake of clarity.

15. Li, Y.; Yan, T.; Junge, K. Beller, M., Angew. Chem. Int. Ed. 2014, 53, 10476-10480. 